\title{
The Union of Saskatchewan Indians: An Organization of Indian People for Indian People
}

\author{
Rauncie Murdoch-Kinnaird
}

\begin{abstract}
The Union of Saskatchewan Indians (USI) had been described as a political tool of the Canadian Commonwealth Federation (CCF). The USI, however, was established and operated independently of the CCF government. Factors which influenced the establishment of the usI included: veterans' involvement, social issues which bonded Indian people together, the education of Indian people, and the support of the Saskatchewan CCF government. Further, the usi operated independently of the CCF government. Its constitution, funding, members, and policies were separate although influenced by the CCF government. Nevertheless, the usi cannot accurately be described as an instrument of the CCF. It was an independent and Indian organization.
\end{abstract}

Soon after its inception, the Union of Saskatchewan Indians (UsI) had to fight the allegation that it was a Cooperative Commonwealth Federation (CCF) creation. In 1947 an article in the CCF paper The Commonwealth stated: "Affidavits submitted to the Joint Parliamentary Committee on Indian Affairs indicate that attempts were made to block the efforts of the UsI on the grounds that it was organized by the CCF." Existing literature on Indian-White relations in the 1940s and 1950 s generally does not address this question. Biographies of T.C. Douglas, the leader of the Saskatchewan CCF during this period, commonly omit reference to Indian-White relations which in fact were a significant part of his government's activity during this period. ${ }^{2}$ Many histories of Indian organizations provide merely a chronology of events, or exclude the view of the Indian people. ${ }^{3}$ While Pitsula addressed the question of the formation of the usi his research inadequately addressed the question of the relationship between the CCF government and Indian people. Pitsula described the CCF and the veterans' movement as causal factors in the establishment of the USI. 
Was the usi formed independently from the CCF? Indeed, the provincial government played a limited but important role in the establishment and organization of the USI. Despite charges that the USI was a CCF creation, the USI was in fact independent. The organization of the usi coincided with several external influences which equally affected the organization's development. First, the end of World War II and the return of many Indian war veterans who would push for their veterans' and Aboriginal rights influenced the organization of the USI. Second, the increasing education of the Indian population would affect Indian politics. Third, Indian people faced many social issues which bound them together. The return of veterans, the education of Indian people, and the stimulus of pressing social issues would influence the formation of several Indian organizations. Finally, the political climate in Saskatchewan created by the CCF government was one sympathetic to Aboriginal people. The CCF encouraged the amalgamation of the Indian organizations into a single provincial association, although the motives of the provincial government in encouraging the organization were significantly different from those of the Aboriginal people. It is important to recognize that the many factors which influenced the formation of the usi cannot and should not be ranked in order of their importance to the formation or operation of the USI. Each factor is significant and may have influenced the many individuals and separate organizations which amalgamated into the USI.

While many factors influenced the formation of the USI, none of them could be described as causal. The fact that many Indian organizations existed prior to the ust indicates that the Indian political movement was not caused by forces in the CCF government. In particular, the League of Indians of Canada had an effect on the usl and its leader, John Tootoosis. The effectiveness of Indian political movements had been hampered by government attempts to stop Indian political organization. Revisions to the Indian Act in 1927 made it illegal to raise funds to pursue any issue relating to Aboriginal rights. Furthermore, the pass system, which impeded travel to meetings, was in effect until the 1950 s. 
Discussion of Indian political movements are often tied to the 1969 White Paper, as if all Indian politics had been initiated by Whites. In fact there were many political Indian organizations prior to the late 1960s. The usi was formed in 1946 when three Indian groups in Saskatchewan amalgamated to form a single organization. Political Indian organizations, however, had existed many years prior to the formation of the USI and were not caused by forces outside Aboriginal communities. Lueger traces the development of Indian associations to the establishment of the Grand General Council in 1870.4 Many of these organizations were formed by Aboriginal people for Aboriginal people with little support or interest from the dominant White community.

John Tootoosis attributed the decline in the number of Aboriginal organizations in the late 1800 s and early 1900 s to a loss of Aboriginal voice. ${ }^{5}$ The 1885 Rebellion and Frog Lake Massacre signaled a loss of power by Aboriginal people. Missionaries and government dominated their lives. It would take some time before Aboriginal people would regain their voice and assert their rights.

There were several Indian organizations in Canada consisting of international, national, and regional associations. The League of Indians of Canada, a national Indian organization, was led by Frederick Ogilvie Loft, and first met in 1918. ${ }^{6}$ An international organization, the League of North American Indian Nations, was started by Lawrence Twoaxe in approximately 1935, , and ended in 1949 with his death. ${ }^{8}$ The North American Indian Brotherhood (NAIB), a strong national organization led by Andrew Paull, began in 1944 and ended in 1959 with Paull's death. ${ }^{9}$ Regional organizations included the League of Indians of Western Canada (LIWC) which began in 1929 as a branch of the League of Indians. The LIWC was initially led by Reverend Edward Ahenehew and later by John Tootoosis. It originally was a Treaty 6 organization and later included some Treaty 5 and 8 Indians. The Alberta members of the LIWC branched off from the Saskatchewan members in 1936; and in 1939 they formed the Indian Association of Alberta under the leadership of John Callihoo. ${ }^{10}$ Manitoba formed a provincial organization in 
1946 called the Manitoba Indian Brotherhood." It is clear that there were many Indian organizations prior to the 1969 White Paper.

From 1921 on, the Chiefs of Saskatchewan had been trying to form a common association. ${ }^{12}$ The usiaccomplished that unification in 1946. It was an amalgamation of three existing Indian organizations. In 1928 a group called the Allied Bands formed from three Treaty 4 bands in the QuAppelle area: Pasqua, Piapot, and Muscowpetung. In 1933 the Allied Bands changed their name to the Saskatchewan Treaty Protection Association and in the 1940s became the Protective Association for the Indians and Their Treaties. ${ }^{13}$ The Association of Saskatchewan Indians formed in 1945 and was lead by Joe Dreaver. ${ }^{14}$ The third organization was the Saskatchewan branch of the LWIC led by John Tootoosis which began in 1930 .

Three meetings led to the establishment of Indian unity in Saskatchewan. The first meeting was on 5 January 1946 in Regina, and was called by Premier T. C. Douglas at the request of Joe Dreaver. ${ }^{15}$ Dreaver explained that he could not call the meeting himself because of his involvement in one of the regional organizations. If Dreaver had called a meeting for the purpose of forming a unified regional organization it may have been interpreted by other groups as the amalgamation of all groups into a stronger, dominant protective association. ${ }^{16}$ The first meeting was well attended by 60 representatives of the Cree, Sioux, Saulteaux, and Assiniboine tribes who passed a resolution to form a single Indian organization. ${ }^{17}$ Representatives of northern Saskatchewan, including Tootoosis, did not attend the first meeting which led to a subsequent meeting at Duck Lake on 10 January 1946. The Saskatchewan branch of the LIWC had already scheduled this meeting and invited the members of the other organizations to attend. The meeting produced overwhelming support for the NAIB, not for a provincial organization, and another meeting was scheduled for Saskatoon to further consult the Indians of northern Saskatchewan. ${ }^{18}$ The third meeting was necessary to produce support for a provincial organization which had not 
been supported earlier at Duck Lake and the government of Saskatchewan was prepared to support a third meeting to produce that support. The third meeting was held in Saskatoon at the Barry Hotel in February 1946. "As a result of deliberations the three groups decided to amalgamate and the new organization was given a name, the Union of Saskatchewan Indians. John [Tootoosis] was elected President, John Gambler was Vice-president."'9

There was opposition to the formation of a provincial Indian organization in the Indian community. John Tootoosis began the Saskatoon meeting by calling for support for the NAIB and a single organization for Canada, not just Saskatchewan. ${ }^{20}$ The CCF strongly pushed for the formation of a strong, representative provincial Indian organization. Indian people had favored the development and support of national and international organizations such as the NAIB and the League of Nations. Indian people, however, were able to use government sympathy for Aboriginals to gain funding and support for a provincial Indian organization. An international Indian organization, the League of Nations, supported the development of the UsI. Lawrence Twoaxe, chairman of the organization, wrote to Douglas: "The members of this Council, with the membership of this organization join in extending to you our appreciation and thanks for the kind consideration, recently given our Saskatchewan Indian people in the City of Regina."21

Further divisions in the Indian community involved opposition to government participation in the organization. Indian people had valid suspicion of the role of Whites in their affairs generated from years of broken trust in dealings with governments. The CCF government was seen as calling and directing the meetings. It was outspoken in its attempt to create a single Indian organization and open about its role in the organization. The prominence of the government was challenged by the Indian people and led to divisions. Significantly, the new organization chose not to adopt the name proposed by the CCF government, the Saskatchewan Indian Federation, as it was seen as linked or similar to the CCF. 
There may have been strong allegiances to the individual organizations which may have opposed the usi. There was concern with the unified organization as drafted by the Saskatchewan government. ${ }^{22}$ These concerns led to the development of a provincial federation, while maintaining the existence of the usI and other individual organizations. ${ }^{23}$

The USI was formed for various reasons, such as: the influence of veterans, social issues, education of Indian people, and the support of the CCF government. Indian people had been discriminated against for years but when Indian veterans went to war they were treated with equality. After fighting side by side with White soldiers and then returning home to continuing discrimination, the endurance of that discrimination changed. ${ }^{24}$ Tootoosis noted that Indian war veterans anticipated gratitude and consideration from Indian Affairs but their expectations were not met. ${ }^{25}$ Pitsula gives veterans a primary role in the establishment of the usl:

Their military experience gave them a greater degree of worldliness and sophistication than they would have otherwise had, and their battlefield accomplishments provided self-esteem and confidence. Having served on equal terms with non-Indian comrades in various branches of the armed forces, they returned to the reserves where the stifling, paternalistic Indian Affairs regime still prevailed. Rapidly demoted from the status of war hero to that of second-class citizen, Indian veterans felt deeply the need for fundamental changes in the way Indians were treated. ${ }^{26}$

Pitsula may have over-estimated the effect of Indian war veterans, particularly their self-esteem and confidence. War veterans, including many Indian war veterans, returned home facing many physical and emotional problems caused by their time at war. ${ }^{27}$ There is no doubt that Indian war veterans provided leadership to the Indian organizations, as Pitsula points out; however, their major concern was with economic issues. 
Social issues such as basic health requirements, including medical services, adequate food and housing, economic concerns and education, were central to Indian political movements. Indian war veterans returned home in dire need of proper medical attention for those who had been injured, and mental health attention for all who had faced the trauma of war. The lack of adequate employment would have affected every member of the reserve and particularly Indian war veterans who had experienced continual employment and a decent income for a period of time.

Furthermore, education was a primary concem of Indian people. Education as provided by missionary residential schools was not seen as valuable and Indian people desperately wanted change. Education may have been a significant factor in the formation of the Usı. Indian people felt that education stimulated Indian political organization. ${ }^{28}$ Tootoosis felt that Indian elders were not aggressive enough in their dealings with government, thus education supported the development of Indian organizations; according to Tootoosis, Indian people began to receive the benefits of education in the late $1920 \mathrm{~s}^{29}$ Education gave them the knowledge to deal with Canadian governments. Interpreters may have been biased and as the Indian people became educated there was no longer the need for interpreters. As English reading and writing skills improved Indian people could study the treaties and their rights as Indians themselves. Indian people were no longer ignorant concerning the issues that affected them and this made it easier to organize politically. This action was supported by the elders according to Tootoosis.

The Saskatchewan government also influenced the amalgamation of Indian groups into the USI. The govemment pushed for the formation of a single provincial Indian organization, and publicly called for Indian unity. ${ }^{30}$ It gave a sympathetic hearing to the plight of the Indian people as is shown by the complaint from the Canadian government that there was an increasing tendency of Indians to bring their problems directly to the premier's office and bypassing Indian superintendents and the regional 
supervisor in Regina. ${ }^{31}$ The government arranged meetings, travel for Indian delegates and other funding, and chaired the three initial conferences which led to the establishment of the USI.

The CCF government stated that it would gain no advantage by furthering the cause of the Indian people. ${ }^{32}$ However, it was receiving good press for its humanitarian efforts on their behalf. Murray Cotterill, director of publicity for the United Steelworkers of America, wrote to Douglas in January of 1946: "I notice by the newspapers that you are about to do something that can be favorably exploited in the Eastern publicity outlets." 33 Naturally, complimentary publicity can be advantageous for governments which are democratically elected to office.

The provincial government recognized that its Indian population was increasing rapidly, ${ }^{34}$ and this would place an increasing burden on the government.

When they commit crimes, they are incarcerated in provincial gaols; when they are ill, they find their way to provincial hospitals for the sick and mentally disturbed; if they are unable to adjust to the communities in which they live, their problem becomes a provincial problem. ${ }^{35}$

The government believed that the Indian problem was one of "segregation" and there was an attempt to solve this through "integration." Pitsula outlines the government's three-part plan to achieve integration of Indian people: "the extension of the provincial franchise (the vote), the removal of restrictions on the sale of liquor to Indians, and the transfer of responsibility for Indian affairs from the federal to the provincial government." ${ }^{36}$ This long-term goal would give the provincial government jurisdiction over Indian Affairs and shift power from the federal government along with the monetary compensation for the delivery of services to Indians who were a federal responsibility. The provincial government stood to gain an 
advantage in pushing for the formation of a single Indian organization. If that organization could be used to show that the federal government was not or could not live up to its responsibilities to Indian people then the provincial government stood to gain power and money with the transfer of jurisdiction of Indian Affairs to the province.

Examination of how the Usi operated further reveals the nature of its connection to the CCF government. There was some involvement with the provincial government; however, the operations of the usi, including its constitution, funding arrangements, provincial government involvement, and its policies, as compared to the policies of the CCF, indicates that the USI was not simply an instrument of the provincial government.

The usi constitution included provisions to prevent influence by political and religious parties. Article II of the usi constitution reads: "The Union shall be democratic and non-sectarian, and shall not directly or indirectly be affiliated to, or connected with any political party." Article IV sets out the guidelines for membership: votes were restricted to Indian people, both treaty and nontreaty. Non-Indian people could be honorary members as long as they "support the spiritual and temporal welfare of the Union," but honorary members were not entitled to a vote. ${ }^{38}$ Article $\mathrm{V}$ refers to who may hold office: "Every member of the Provincial or Executive Council must be of Indian ancestry and of good moral character, to be eligible to hold office in the Union." 39 The constitution also provided that " $[u]$ nless authorized at a Union meeting of which due notice shall be given, no officer or member of the Union shall receive remuneration for his services." 40 The usı constitution was an attempt to enforce non-partisan and non-sectarian rules on the organization. According to the constitution it was a distinctly Indian organization composed of Indian members and officers. However, honorary, non-Indian members would still be influential. The remuneration clause is important in that there was an attempt to 
protect the organization from the influences of those who could provide monetary compensation to the USI.

The constitution also allowed members to retain their memberships in other organizations. When the three Indian organizations amalgamated, the original three groups did not dissolve. The structure of the federation then allowed other organizations to continue, which offered alternative bodies for members who dissented from the positions the ust would take. This factional force would prove to be a major factor in the downfall of the Usi.

The USI constitution provided that all members pay a one dollar membership fee, an amount that would prove to be inadequate to fully fund the organization. Tootoosis explained that many costs of the organization, such as travelling to meetings, were incurred by individual members and officers. ${ }^{41}$ This ensured that members were dedicated to the cause, according to Tootoosis. Obviously, the Indian population, already stricken by poverty, could not alone afford to support the organization. Hence, the CCF government also helped fund the USi. The government helped to finance the initial three meetings that led to the creation of the USI. ${ }^{42}$ It received many letters from Indian people requesting that it make arrangements for reduced travel rates or provide accommodation for USI delegates. ${ }^{43}$ Tootoosis stated:

[Douglas] advised [the usl] to ask the federal government for help in funding - whatever they were able to get, his government would match. However, this had been overoptimistic advise. Ottawa would not provide money for such a purpose. Even so, Mr. Douglas did make funds available for meeting purposes. ${ }^{44}$

The government continued to make funds available for USI meetings, arranging and funding the 1950 conference in Prince Albert. ${ }^{45}$ In 1958, the Usi became the Federation of Saskatchewan Indians (FSI); Pitsula notes that this was the beginning of provincial government 
financial support of the uss ${ }^{46}$ Funding from the provincial government, however, had been given to the usi prior to the 1958 grant of $\$ 1,000$ to cover transportation expenses. Also, the government hosted the 1958 conference and paid $\$ 5,707 .{ }^{47}$ It sent out invitations to the conference, made arrangements for when and where it would be held, for delegates' travel, and accommodation. ${ }^{48}$ This marked the beginning of more substantial and consistent provincial government funding. While it played a role in supporting the USI financially it is not clear that this gave the provincial government influence over USI policy.

The government did influence the USI in other ways. Its representatives attended and advised the USI at many conferences. Morris Shumiatcher, a legal advisor for the CCF government, chaired the 1946 conference in Saskatoon where the usI was formed. ${ }^{49}$ The provincial Minister of Natural Resources, Joseph Phelps, was often in attendance at usi conferences, as were Premier Douglas and Yorkton MP, G.H. Castledon.

The CCF and the USI employed the same lawyer, Shumiatcher, who acted as an advisor and prepared briefs for the USI. Due to his involvement with the government he does not appear to have been an impartial assistant. As The Commonwealth reported in "Indian Brief is Endorsed," it seems that the CCF prepared and submitted briefs to the UsI which altered the briefs. The usı endorsed the briefs rather than the briefs being an original product of the organization. ${ }^{30}$ Also, the USI constitution had been already drafted by the government when presented to delegates in Regina, although it was subsequently altered by Indian delegates. ${ }^{51}$

The NAIB strongly opposed the provincial government's involvement in the Union. Andrew Paull, the NAIB president, wrote to Premier Douglas asking him to stop the interference of Whites, and particularly Shumiatcher, 
in Indian attempts to organize..$^{52}$ It should be noted that Andrew Paull had his own aspirations and opposed the USI and favored the development of a provincial branch of the NAIB instead. This might have affirmed the existing Indian push for independence from the government. Douglas responded to Andrew Paull's letter, writing that: "I am pleased to be able to say that [the USI] is functioning in a free and democratic fashion, and remains uninfluenced by any group or organization, whether political or otherwise." 53 Likewise, Douglas also had motivations for the continuation of the usI and the promotion of the usi as an independent organization.

The CCF government had a separate agenda from that of the Usı. Its three-part plan was integrationist and not informed by Indian people. Stan Cuthand, although he supported certain measures taken by the CCF, saw that their policy was paternalistic: "They [the government] went ahead and did things. They imposed policy. Indian people had no voice, no vote on issues." 54 The government felt that it knew what was in the best interest of Indian people. While its intentions may have been good, policy was still imposed on Indian people. Allan Quandt, a CCF member and an administrator in the north under Joseph Phelps, stated that "the CCF was prone to saying that is a good idea, we'll do it for you, as opposed to letting Indian people do it for themselves."ss

The issue of the vote and liquor rights illustrates that the USI and the government had separate agendas, and the USl opposed the CCF's paternalistic policy. In practice, the USI was not a simple instrument of the CCF. The government had a vision of equality for all citizens, and believed that The Indian people would never be equal as long as they did not enjoy the same rights under the law as other provincial citizens, namely the right to vote and drink liquor. The usi, however, did not agree with the provincial government's plans to give them these rights.

The usI opposed the offer due to a fear of losing treaty rights. This may have been caused by a confusion between 
"enfranchisement" and "franchisement," and some foresaw many problems with liquor. According to Indian people, treaties were with the federal government and signed between "nations." Voting in another nation's elections was seen as limiting treaty rights. Throughout the 1950 s many Indian people called for reassurance that the right to vote would in no way limit treaty rights and eventually, in 1960, the CCF government issued a letter to that effect. ${ }^{56}$ "Enfranchisement" refers to the loss of status and all rights derived from being a status Indian person. "Franchisement" refers to the right to vote and does not involve any loss of treaty rights. Many Indian people used the two terms interchangeably and therefore saw the right to vote as linked with the loss of status.

Further, many Indian people also saw the right to drink liquor as the imposition of the evils of alcohol: "As for the firewater, the majority of Indians are clamoring for the rights and privileges of the beer parlor-but the best thinking Indians are opposed to this demoralizing agent,-the firewater."'T7 There were many UsI members concerned about the negative consequences that the sale of liquor would have in Aboriginal communities.

The usi did not support the CCF government's attempt to impose the vote or the sale of liquor on Indian people. As early as 1948, the USI submitted a brief to the federal govemment:

The Union has taken the position that a vote should be given to Indians upon an individual basis and only after Indians have decided that they wish to exercise the franchise. In the past, enfranchisement has meant loss of treaty rightsthe one benefit the Indians do not wish to lose. The vote is the White man's edge of the wedge to take from us our remaining privileges, said the spokesman. The Indians of Saskatchewan want nothing to do with the general franchise, they said. Any political party that believes that it will gain advantage by offering us the franchise is very much mistaken. We wish to remain as Indians and to preserve our identity and our ways. ${ }^{58}$ 
At annual conferences, the usI continued its position against the right to vote and the sale of liquor to Indians . Some Indian people, such as Dan Kennedy and Joe Ironquill, supported the vote..$^{59}$ In 1952 the CCF government had promised that no legislation would be passed concerming the right to vote or to drink liquor without the consent of the Indian people. ${ }^{60}$ Without the consent of Indian people, however, legislation was tabled in 1956 to give the Indian people the right to vote and liquor privileges. ${ }^{61}$

Premier Douglas sought the consent of Indian people at the October 1958 usı conference at Valley Centre, Fort $\mathrm{Qu}$ 'Appelle. The usI discussed the vote and liquor but made no decision except to vote on the issues at the next year's conference..$^{62}$ In its 1959 conference, the USI (now the FSI) again tabled and discussed the issues of the vote and liquor, but again no decision was made. ${ }^{63} \mathrm{An}$ amendment to the Saskatchewan Liquor Act giving Indian people the right to purchase liquor off reserve passed in 1959.64 Indians were given the right to vote in 1960. Legislation was passed without the consent of the Indian people or the FSI and against the promises made by Premier Douglas and his government. The government, however, was compelled to push the issue of the vote and the right to drink liquor due to federal legislation. In 1956 federal legislation delegated responsibility to the provincial governments for liquor legislation in regard to Indian people. In 1960 the federal Bill of Rights was passed and other provinces were granting the franchise. Although the Saskatchewan government was compelled to address these issues, the CCF attempted to legitimize its decisions by gaining the consent of the USI, but it was unable to do so.

The USI and later the FSI, were independent from the CCF government. Indian people, however, were aware of CCF involvement in the USI and there was a push for independence by Indian people. In general, Indian people were suspicious of any government. This distrust of government had existed for many years prior to the establishment of the USI, and did not dissipate even with the sympathetic hearing and aid of the CCF. Treaty 
promises remained unfulfilled many years after treaties had been signed. There were no farm implements, no schools, and little aid for the starving, all of which had been promised by treaty. ${ }^{65} \mathrm{John}$ Tootoosis, leader of the USI for 22 years and then leader of the FSI for three years, had a very suspicious attitude toward Whites. In an interview with Murray Dobbin, Tootoosis stated that he did not trust White people and questioned the interviewer's intentions and refused to answer many questions. ${ }^{66}$ Even the CCF government recognized the suspicious attitude of the Indian people. ${ }^{67}$

The usi made several attempts to state its independence from the CCF. A submission to the Special Joint Committee of the Senate and the House of Commons appointed to examine and consider Indian Affairs in 1947 heard:

We wish to make it clear at the outset, that we are not a White man's organization, nor are we dominated by any White men, as has been suggested by some. Our representations make it clear that we are not interested in saving the face of any White man or any group of White men; we speak clearly and bluntly, and our thoughts and aims are the thoughts and aims of the great majority of the Indian people in Saskatchewan. ${ }^{68}$

Non-Indian participants at conferences stressed that they were not participating in order to dominate the Indian people. While chairing the 1946 conference in Saskatoon, Shumiatcher stated: "The conference is not a political one; it is not called by any political party; it makes no political demands." ${ }^{69}$ At the same conference, Phelps stated: "I want to emphasize that I am not here to assert any political influence whatsoever." ${ }^{.70} \mathrm{~A}$ headline in the CCF paper read "Saskatchewan Indians Are Running Own Affairs." "There was a need to emphasize the independence of the usI.

Indian people attempted to limit non-Indian participation and influence at usi conferences. At the Duck Lake conference in January of 1946, discussion was dominated by Indian 
people and they were in control. After Yorkton MP, G.H. Castledon spoke at the conference it was recorded: “Although Mr. Castledon's remarks seemed to please the assembly, Chief Donald Gambler requested that the deliberations of the conference be not interfered with by outsiders and be strictly limited to Indians only."72 At the Saskatoon conference in February of 1946, Tootoosis insisted on Cree being spoken. ${ }^{73}$ This would effectively block non-Indian participation and illustrates Indian control over the proceedings. E. A. Boden wrote to Premier Douglas that the Indian people were capable of handling their own affairs and were doing so:

John told me that just recently he had to warn Shumiatcher who apparently was attending one of the meetings lately of the danger in being a little too ready to offer advise to the Indian. To sum it all up they are not in a mood to have anyone tell them how they should run their affairs. ${ }^{74}$

Independence of the USI is clearly demonstrated by its adherence to the view of Indian people as a separate nation. The LIWC was one of the three organizations which amalgamated to form the USI. The policy of the LIWC and its parent organization, the League of Indians of Canada (LIC), included recognition of self-determination. In 1919 the LIC made its view on Indian nationhood clear:

We will co-operate with the Government, but we must have its sympathy, encouragement and assistance to make good. To force or coerce us will do no good; justice and fair dealing is what we ask for. We are men, not imbeciles; from our point of view and standpoint we must be heard as a nation when we have to speak for ourselves. ${ }^{75}$

A letter to Shumiatcher in 1948 reads: "I hope someday before very long I will make my own laws as an Indian when the red people have regained their rightful status as a nation, this time, within a nation." 76 The 1960 brief to the Joint Committee of the Senate and the House of Commons by 
the FSI included the idea of Indian people as a nation." Although the Senate hearings ignored this idea, Tootoosis says "they cannot break it." Self-government for Indian people was the goal of Indian people even in the 1940s and 1950 s although the concept of self-government was primarily seen as control and jurisdiction over reserve lands.

In 1958 the usl became the FSI. The USI was flawed in that it had allowed members to retain memberships in other organizations and this produced dissent and factions within the Usi. John Tootoosis said:

The way things are now and the way we [the usI] stand, some groups are still trying to separate from the Union. We are weakening ourselves .... A lot of important things are happening concerning us, and being discussed, and we can't even discuss them among ourselves. We have to amalgamate again and get together. We will give our organization another name. ${ }^{78}$

The USI evolved into the FSI. In 1982 the FSt agreed to restructure the organization from a non-profit society to a true Indian government called the Federation of Saskatchewan Indian Nations (FSIN). Currently, the FSIN is a very powerful organization in Saskatchewan. The USI was also a powerful Indian political organization in its time and it was an Indian organization through and through. The FSIN has a proud heritage with the usi, a strong and independent organization ahead of its time demanding Aboriginal rights and recognition for Indian people as a nation.

"Evidence at Ottawa Reveals Opposition to Indian Union," The Commonwealth, 11 June 1947; see also, Jean Goodwill and Norma Sluman, John Tootoosis (Winnipeg: Pemmican Publications, 1992), 188; this is an excellent reader on Indian organizations and a study of one leader in particular.

'Dorris French Shackleton, Tommy Douglas (Halifax: Goodread Biographies, 1975). This book provides some mention of the CCF government's policy toward Aboriginal people and the achievements accomplished by the government. 
3Pitsula, "The Saskatchewan CcF Government and the Treaty Indians" The Canadian Historical Review 125 (1) (1994); Richard R.H. Lueger, "A History of Indian Associations in Canada" (MA diss., Carleton University, 1977); Goodwill and Sluman, Tootoosis.

"Lueger, "History of Indian Associations."

${ }^{3}$ Good will and Sluman, Tootoosis, 85.

${ }^{6}$ Ibid., 128.

'Ibid., 162.

${ }^{8}$ Ibid., 200.

'Ibid., 201.

${ }^{10}$ Ibid., 173.

"lbid., 187.

${ }^{12}$ Ibid., viii.

'3lbid., 146; see also, FSIN, "Laying the Foundation," FSIN Annual Reporl, 1993.

${ }^{14}$ Goodwill, Tootoosis, 177; also, FsIN, "Laying the Foundation," states that the Association of Saskatchewan Indians formed in 1943.

15Don Whiteside, "Efforts to Develop Aboriginal Political Associations in Canada, 1850-1965," Aboriginal Institute of Canada, Ottawa (unpublished ms), 81.

${ }^{16}$ Don Whiteside, "Efforts to Develop Aboriginal Political Associations," 81.

17FSIN, "Laying the Foundation."

${ }^{18}$ Goodwill and Sluman, Tootoosis, 187.

${ }^{19}$ Ibid., 188.

${ }^{20}$ Saskatchewan Archives Board (SAB), T.C. Douglas Papers, collection no. R33.1 File no. XLV.864(a)49, "Indian Missionary Supplement," February 1946.

${ }^{21} \mathrm{SAB}, \mathrm{T} . \mathrm{C}$. Douglas Papers, collection no. R33.1, file no. XLV.864(a)49, Letter to Douglas from Lawrence Twoaxe, 21 January 1946.

${ }^{22} \mathrm{SAB}, \mathrm{T} . \mathrm{C}$. Douglas Papers, collection no. R33.1, file no. XLV.864(a)49, "Indian Missionary Supplement," February 1946.

"Pitsula, "The Saskatchewan ccF Government and the Treaty Indians," James Pitsula, "The CCF Government and the Formation of the Union of Saskatchewan Indians," Prairie Forum 19 (2) (1994); Lueger, "A History of Indian Associations"; Whiteside, "Efforts to Develop Aboriginal Associations."

${ }^{24}$ Interview by author with Gordon Ahenehew, 6 February 1995.

${ }^{23}$ Goodwill and Sluman, Tootoosis, 185.

${ }^{26}$ Pitsula, "The CCF Government and the Formation of the Union of Saskatchewan Indians," 131.

${ }^{27}$ Interview with Ahenehew.

${ }^{28}$ Interview by author with Stan Cuthand, 30 January 1995. 
${ }^{29} \mathrm{SAB}$, interview with John Tootoosis by Murray Dobbin, 11 September 1977. RA1178.

30"'Saskatchewan Premier Urges Indians Unite," The Regina Leader Post, 28 December 1945, 3.

${ }^{31} \mathrm{SAB}$, T.C. Douglas Papers, collection no. R33.2, file no. XXIl.409, Letter to Douglas from A. Mackinnon, Canada Minister of Mines and Resources, 19 July 1948.

${ }^{32}$ Adult Education Division, Department of Education, Regina, "Premier T.C. Douglas," Saskalchewan Community, February, 1960. ${ }^{33}$ SAB, T.C. Douglas Papers, collection no. R33.1, file no. XLV.864(a)49, Letter to Douglas from Murray Cotterill, 3 January 1946.

${ }^{34}$ SAB, T.C. Douglas Papers, collection no. R33.1, file no. XLV.864(f)49, Joint Committee of the Senate and the House of Commons on Indian Affairs, A submission of the Government of Saskatchewan, February 1960.

${ }^{39}$ SAB, T.C. Douglas Papers, collection no. R33.1, file no. XLV.864(a) 49, "Indians."

${ }^{36}$ Pitsula, "The Saskatchewan CCF Government and the Treaty Indians," 30.

${ }^{31} \mathrm{SAB}, \mathrm{T}$.C. Douglas. "The Union of Saskatchewan Indians: The Record of the Establishment of Indian Unity in Saskatchewan," March 1946, call no. EC3, file no. 8: 1 .

${ }^{38}$ Ibid., 1.

${ }^{30}$ Ibid., 3.

"Ibid., 4.

${ }^{41} \mathrm{SAB}$, interview with John Tootoosis by Murray Dobbin.

${ }^{42}$ Goodwill and Sluman, Tooloosis, 188; see also, SAB, T.C. Douglas Papers, collection no. R33.1, file no. XLV.864(a) 49, Letter to Mr. J. Kinequon from Douglas, 21 February 1946; see also, Pitsula, "The CCF Government and the Formation of the Union of Saskatchewan Indians," 140.

${ }^{43}$ SAB, T.C. Douglas Papers, collection no. R33.2, file no. XXII.401, Letter to Shumiatcher from Peter Watson; see also, "A New Means of Livelihood Needed for Indians," The Commonwealth, 30 April 1947.

${ }^{4}$ Goodwill and Sluman, Tootoosis, 202.

${ }^{43}$ SAB, T.C. Douglas Papers, collection no. R33.1, file no. XLV.864(b) 49, Letter to Douglas from usı Secretary Gladys Johnson, 2 October 1950.

${ }^{46}$ Pitsula, "The Saskatchewan CCF Government and the Treaty Indians," 34.

${ }^{47} \mathrm{SAB}, \mathrm{T} . C$. Douglas Papers, collection no. R33.1, file no X.396, Letter from H.S. Lee to A.W. Johnson, 17 November 1958. 
${ }^{48}$ SAB, T.C. Douglas Papers, collection no. R33.1, file no. XLV.864(d) 49, Letter to all Indian Chiefs and Councilors in Saskatchewan from J.H. Sturdy, 22 September 1958.

${ }^{49}$ SAB, T.C. Douglas, "The Union of Saskatchewan Indians," 57.

so" Indian Brief is Endorsed," The Commonwealth, 6 November 1946, 2 ; emphasis added.

"Goodwill and Sluman, Tootoosis, 141; see also, Pitsula, "The cCF Government and the Formation of the Union of Saskatchewan Indians," 141.

${ }^{52}$ SAB, T.C. Douglas Papers, collection no. R33.1, file no. XLV.864(a) 49, Letter to Douglas from Andrew Paull, 2 October 1946.

s3 Ibid., 8 October 1946.

${ }^{54}$ Interview by author with Stan Cuthand, 30 January 1995.

ss Interview by author with Allan Quandt, 16 January 1995.

${ }^{36} \mathrm{SAB}, \mathrm{T} . \mathrm{C}$. Douglas Papers, collection no. R33.1, file no. XLV.864(e)

49, Letter 10 "My Indian Friends" from Douglas, 30 May 1960.

${ }^{57}$ SAB, T.C. Douglas Papers, collection no. R33.1, file no. XLV.864(c)

49, Letter from Dan Kennedy to Douglas, 17 February 1956, 2; emphasis added. Dan Kennedy was a prominent Indian leader in Saskatchewan. He was a product of residential schools and became very well educated. He went on to teach at St. Boniface Residential School. Dan Kennedy was an exceptional person and was not representative of the general Indian population when he made these remarks.

${ }^{88}$ SAB, T.C. Douglas Papers, collection no. R33.2, file no. XXII.396, usI to Joint Committee of the Senate and House of Commons, 7 May 1948.

596"Indians Urged to Use Vote," The Commonwealth, 27 April 1960, 2

${ }^{60} \mathrm{SAB}, \mathrm{T} . \mathrm{C}$. Douglas Papers, collection no. R33.1, file no. XLV.864(b) 49, Letter from A.I. Morison to Douglas, 16 April 1952. Note: there are many similar letters in this file.

${ }^{61} \mathrm{SAB}, \mathrm{T} . \mathrm{C}$. Douglas Papers, collection no. R33.1, file no. XLV.864(c) 49, Letter to Dan Kennedy from Douglas, 23 February 1956.

${ }^{62}$ SAB, T.C. Douglas Papers, collection no. R33.1, file no. XLV.864(d) 49, Report on the Provincial Conference from J. Sturdy; see also Goodwill and Sluman, Tootoosis, 203.

${ }^{60}$ Goodwill and Sluman, Tootoosis, 204.

${ }^{6}$ SAB, T.C. Douglas Papers, collection no. R33.1, file no. XLV.864(e) 49, Letter to all CCF candidates from Sturdy, 15 April 1960, 1.

${ }^{69}$ Goodwill and Sluman, Tootoosis, 25-27.

${ }^{66} \mathrm{SAB}$, Dobbin interview with Tootoosis.

${ }^{67}$ Adult Education Division, Saskatchewan Community, February, 1960. 
${ }^{68} \mathrm{SAB}$, file no. G1 88.2, "Submission to the Special Joint Committee of the Senate and the House of Commons appointed to examine and consider Indian Affairs," May 1947, 1. ${ }^{69} \mathrm{SAB}$, T.C. Douglas, The Union of Saskatchewan Indians, 57. ${ }^{70}$ Ibid., 57.

"Saskatchewan Indians Are Running Own Affairs," The Commonwealth, 7 May 1947, 7.

"SAB, T.C. Douglas, The Union of Saskatchewan Indians, 53; see also, SAB, T.C. Douglas Papers, collection No. R33.1, file no. XLV.864(a) 49, "Indian Missionary Record Supplement," February 1946. Although this publication records this event as occurring at the Saskatoon meeting in February of 1946, I believe that the incident occurred in Duck Lake on Gambler's reserve.

"Pitsula, "The CCF Government and the Formation of the Union of Saskatchewan Indians," 141.

${ }^{4} \mathrm{SAB}$, collection no. XLV.864(a) 49, Letter from Mr. E.A. Boden to Douglas, 24 June 1946.

"Peter A. Kulchyski, "A Considerable Unrest: F.O. Loft and the League of Indians," Native Studies Review 4 (1 and 2) (1988): 101; emphasis added.

${ }^{76}$ SAB, collection no. R33.2, file no. XXII.399, Letter to Shumiatcher from Emest Goforth, 29 March 1948.

"SAB, Interview with John Tootoosis by Murray Dobbin.

${ }^{18}$ Goodwill and Sluman, Tootoosis, 203. 